\title{
Modeling of the Regional Forest Sector to Improve Economic and Legal Relations in Forest Management
}

\author{
Anton I. Pyzhev* and Evgeniya V. Zander \\ Siberian Federal University \\ 79 Svobodny, Krasnoyarsk, 660041, Russia
}

Received 03.09.2019, received in revised form 31.10.2019, accepted 07.11.2019

The diversity of the problems of forestry in Russia requires a new common approach to solving them. One option is to conduct a comprehensive study of the factors influencing the development of the forest sector from different perspectives including climate change problem. The general logic of the analysis is based on the premise that the forest economy is in a mutual relationship with the climate change process. One of the major challenges for the future development of the Russian forestry are the insect pests' outbreaks, which cause forest fires and tree losses on vast territories, especially in Siberia. Economic and legal research on this aspect of forest sector development is still lacking. We suggest to design a new Integrated Assessment Model of the Russian forest sector with a special focus on the regions of Siberia, which will include key components reflecting microeconomic linkages within the sector, the macroeconomic environment, resource base dynamics, climate change trends and international trade. Forecasts made using this model will allow policy-makers to understand in depth both the possible effects of different measures and the effects of exogenous factors, such as forest fires and insect pests.

Keywords: forest economics, economic modeling, forest sector, climate change, partial equilibrium models.

The study was funded by the Russian Science Foundation (project no. 19-18-00145).

Research area: economics and national economy management.

Citation: Pyzhev, A.I., Zander, E.V. (2019). Modeling of the regional forest sector to improve economic and legal relations in forest management. J. Sib. Fed. Univ. Humanit. Soc. Sci., 12(11), 2091-2096. DOI: 10.17516/1997-1370-0515.

(C) Siberian Federal University. All rights reserved

* Corresponding author E-mail address: apyzhev@sfu-kras.ru

ORCID: 0000-0001-7909-3227 (Pyzhev); 0000-0002-2135-5084 (Zander)

This work is licensed under a Creative Commons Attribution-NonCommercial 4.0 International License (CC BY-NC 4.0). 


\section{Introduction}

Economics of the Russian forest sector suffers from the lack of fundamental studies of the factors influencing its performance. There are very few on mathematical modelling of specific domains of intersectoral and international trade flows, dynamics of product structure, resource base, impact of climate change, law regimes and other institutional factors. Considering the multiple problems of the forest industry in Russia, there's a need for new comprehensive studies based on mathematical modeling (Gordeev, 2018; Glazyrina et al., 2015).

Antonova (2018) has made a review of studies on modeling of the regulation impacts on the economic performance of Russian forest sector. It is also worth to mention some recent papers suggesting to apply the agent-based modelling approach to investigate the intersectoral interactions between different kind of actors (Gulin, Antonov, 2017). The only known example of the macroeconomic work of this type is the study of Solberg et al. (2010), which explored the Russian and world market response on the higher export tariffs on unprocessed timber in the late 2000s.

Latta et al. (2013) give a comprehensive survey of dozens of different models of forest sectors at international, national and regional scale since $1980 \mathrm{~s}$. It is stated that the approach to model the forest sector has undergone a major shift over the last two decades being influenced by multiple factors including climate change. The structural diversity of all models is explained by the different challenges they were designed to address: from very simple tasks like prediction of future timber prices on the local market to very detailed studies of national forest sector behavior under various conditions.

\section{Model Design}

The general logic of the analysis is based on the premise that the forest economy is in a mutual, i. e. two-way relationship with the climate change process. On the one hand, human economic activity leads to significant and rapid changes in the state of forests due to harvesting, which affects the sustainability of ecosystems (biomass reproduction processes, carbon storage). On the other hand, natural and anthropogenic climate changes are able to influence qualitative and quantitative characteristics of forest resources (species composition, areas of growth, growth rate, impact of forest fires and forest pests, etc.). Thus, the analysis of the problem should take into account the diverse nature of interactions between climate change and human activities. 
Climate change has become a new global challenge, increasingly perceived by society as a whole and by some experts and politicians as a source of potential danger to the population and material assets accumulated by mankind throughout its history. Climatic dynamics can have an impact not only on social well-being, but also on the natural environment, which serves as both a place of human habitation and a resource base for meeting the needs of society. Natural disasters, such as storms, floods, droughts, forest fires, mass reproduction of phytophages and processes of gradual degradation of ecosystems have become the most important manifestations of the impact of global warming on human economic activity (Porfiriev, 2015).

One of the major challenges for the future development of the Russian forestry are the insect pests' outbreaks, which cause forest fires and tree losses on vast territories, especially in Siberia (Kerchev, 2014). There is still no efficient way known to prevent such phenomena, but it is possible to design and implement new policies aimed to stimulate the forest-owners to remove the affected wood outside the forests and to (Grodzki et al. 2006; Ivantsova et al., 2019; Mezei et al., 2019). As these consequences of the climate change may destroy the resource base, there is an urgent need to implement the model, which could consider all the major factors influencing the future supply of timber from the Russian forest sector.

The main limitation for modeling any Russian sector of the economy is the lack and poor quality of the initial data. The officially available datasets from public entities (Rosstat, Rosleskhoz) are quite superficial and sometimes contain systematic and casual distortions making them an improper information source for policy-making. Thus, a thorough work needs to be done when selecting the appropriate set of variables and links between them that will serve as a fundamental basis of the model.

The model we suggest to use for solving the stated problem should be of Integrated Assessment Model (IAM) class. As in previous studies, it is assumed that the model will be a set of equations, which is solved under the condition of achieving partial equilibrium in the classical form ${ }^{1}$. We argue that such a model for Siberian regions should include the following blocks: (a) internal resource flows, (b) macroeconomic environment, (c) dynamics of resource base, (d) climate change tendencies and linked phenomena, i. e. pests' outbreaks, (e) international trade flows. The description of components mentioned above requires much more space than the letter format can afford, so this work will be published at a later date.

A detailed explanation of the choice between general and partial equilibrium models is given, e. g. by Eriksson (2015). 
The developed model should provide reliable forecasts of the main indicators of the state of the forest sector, taking into account different scenario conditions: changes in market and general macroeconomic conditions, short-run and long-run climate change tendencies, etc. In order to build such forecasts, a set of different scenario conditions will be formed, which can be considered within the framework of available knowledge on ecosystem dynamics, as well as possible options for changing the macroeconomic conditions of the forest sector.

Calculations made using the model can become the basis for the formation of proposals to improve the legislative framework of the industry in order to achieve high rates of development.

\section{Conclusion}

In recent years, new challenges have emerged in the forest sector that will shape the future of the industry. One of the major enemies of Siberian forests are the climate change-induced insect pests' outbreaks that represent not only a direct, but also indirect threat, contributing to the rapid spread of fires. Ignoring the problem will lead to unwanted consequences, specifically the loss of major part of commercially available wood.

It is suggested to develop a new Integrated Assessment Model of the Russian forest sector with a special focus on the regions of Siberia. This model should include key components reflecting microeconomic linkages within the sector, the macroeconomic environment, resource base dynamics, climate change trends and international trade. Forecasts made using this model will allow policy-makers to understand in depth both the possible effects of different measures and the effects of exogenous factors, such as forest fires and insect pests.

\section{References}

Antonova, N.E. (2018). Evaluation of Economic Agents Responses of on Institutional Changes in the Region Forest Complex. In Prostranstvennaya Ekonomika, 4, 115-138. DOI: $10.14530 / \mathrm{se} .2018 .4 .115-138$.

Eriksson, M. (2015). The Role of the Forest in an Integrated Assessment Model of the Climate and the Economy. In Climate Change Economics 06 (03): 1550011. DOI: 10.1142/S2010007815500116.

Glazyrina, I.P., Yakovleva, K.A., Zhadina, K.A. (2015). Social and Economic Effectiveness of the Forest Use in the Russian Regions. In Regionalistika, 2, 5-6, 18 33. DOI: $10.14530 /$ reg.2015.5-6. 
Gordeev, R.V. (2018). Improving the Competitiveness of the Forest Products: New Lessons from the Trade Analysis. In EKO, 8, 63-84.

Grodzki, W., Jakuš, R., Lajzová, E., Sitková, Z., Maczka, T., Škvarenina. J. (2006). Effects of Intensive versus No Management Strategies during an Outbreak of the Bark Beetle Ips Typographus (L.) (Col.: Curculionidae, Scolytinae) in the Tatra Mts. in Poland and Slovakia. In Annals of Forest Science, 63 (1), 55-61. DOI: 10.1051/forest:2005097.

Gulin, K., Antonov, M. (2017). Theoretical Aspects of Agent-Based Modeling in the Development of the Forest Complex. Economic and Social Changes: Facts, Trends, Forecast, 6 (54). DOI: 10.15838/esc.2017.6.54.4.

Ivantsova, E.D., Pyzhev, A.I., Zander, E.V. (2019). Economic Consequences of Insect pests outbreaks in boreal forests: a literature review. In J. Sib. Fed. Univ. Humanit. soc. sci., 12(4), 627-642. DOI: 10.17516/1997-1370-0417.

Kerchev, I.A. (2014). Ecology of four-eyed fir bark beetle Polygraphus proximus Blandford (Coleoptera; Curculionidae, Scolytinae) in the west Siberian region of invasion. In Russian Journal of Biological Invasions, 5(3), 176-185. DOI:10.1134/ S2075111714030072

Latta, G.S., Sjølie, H.K., Solberg, B. (2013). A Review of Recent Developments and Applications of Partial Equilibrium Models of the Forest Sector. In Journal of Forest Economics, 19 (4), 350-60. DOI: 10.1016/j.jfe.2013.06.006.

Mezei, P., Potterf, M., Škvarenina, J., Rasmussen, J. G., Jakuš, R. (2019). Potential Solar Radiation as a Driver for Bark Beetle Infestation on a Landscape Scale. In Forests, Trees and Livelihoods 10 (7), 604. DOI: 10.3390/f10070604.

Porfiriev, B. (2015). Climate change as a major slow-onset hazard to development: An integrated approach to bridge the policy gap. In Environmental Hazards, 14, 2 , 187-191. DOI: 10.1080/17477891.2015.1019823.

Solberg, B., Moiseyev, A., Kallio, A.M.I., Toppinen, A. (2010). Forest Sector Market Impacts of Changed Roundwood Export Tariffs and Investment Climate in Russia. In Forest Policy and Economics, 12, 1, 17-23. DOI: 10.1016/j.forpol.2009.09.016. 


\title{
Моделирование регионального лесного комплекса \\ с целью совершенствования \\ экономико-правовых отношений \\ в управлении лесами
}

\author{
А. И. Пыжев, Е. В. Зандер \\ Сибирский федеральный университет \\ Россия, 660041, Красноярск, пр. Свободньй, 79
}

\begin{abstract}
Разнообразие проблем лесного хозяйства в России требует нового общего подхода к их решению. Один из таких подходов заключается в проведении всестороннего изучения факторов, влияющих на развитие лесного сектора, с различных точек зрения, в том числе с учетом проблемы изменения климата. Общая логика анализа основана на предположении, что лесная экономика находится во взаимосвязи с процессом изменения климата. Одной из главных проблем для будущего развития лесного хозяйства России являются вспышки численности насекомых-вредителей, которые вызывают лесные пожары и гибель деревьев на обширных территориях, особенно в Сибири. Экономикоправовые исследования по данной проблеме развития лесного сектора ранее практически не проводились. Мы предлагаем разработать новую модель лесного сектора России с особым вниманием к регионам Сибири, которая будет иметь ключевые компоненты, отражающие внутренние микроэкономические связи, макроэкономическое окружение, динамику ресурсной базы, тенденции изменения климата и международную торговлю. Прогнозы, сделанные с использованием этой модели, позволят лицам, принимающим решения, глубже понять как возможные последствия различных мер государственной политики, так и степень воздействия экзогенных факторов, таких как лесные пожары и насекомые-вредители.
\end{abstract}

Ключевые слова: экономика лесного хозяйства, экономическое моделирование, лесной комплекс, изменение климата, модели частичного равновесия.

Исследование выполнено за счет гранта Российского научного фонда (проект № 19-18-00145).

Научная специиальность: 08.00.05 - экономика и управление народным хозяйством. 